\title{
Pengaruh Rasio Likuiditas Terhadap Kinerja Keuangan Ditinjau Dari Return On Assets (ROA) Pada PT. Matahari Putra Prima Tbk Di Bursa Efek Indonesia
}

\author{
Armalinda \\ Sekolah Tinggi Ilmu Ekonomi Serelo Lahat \\ armalinda.stie@gmail.com
}

\begin{abstract}
ABSTRAK
Penelitian ini bertujuan untuk mengetahui seberapa besar pengaruh Rasio likuiditas (CR,QR,CR) terhadap kinerja keuangan ditinjau dari ROA pada PT.MATAHARI PUTRA PRIMA TBk. Rancangan penelitian yang digunakan dalam penelitian ini adalah penelitian Asosiatif / Kuantitatif. Populasi dalam penelitian ini adalah Laporan Keuangan PT Matahari Putra Prima Tbk yang tercatat di Bursah Efek Indonesia, sedangkan sampel yang diambil menggunakan data time series yaitu laporan keuangan PT. Matahari Putra Prima Tbk selama 10 tahun, data yang digunakan dari tahun 2008 sampai dengan tahun 2017. Hasil nilai koefisien determinasi ( $R$ Square) sebesar 0.822. Angka tersebut dapat diartikan bahwa Current Ratio, Quick Ratio dan Cash Ratio berpengaruh signifikan terhadap ROA sebesar $82,2 \%$ sedangkan sisanya $17,8 \%$ dipengaruhi oleh variabel lain diluar penelitian. Hasil uji statistik menunjukkan secara parsial variabel Current Ratio berpengaruh signifikan terhadap Return On Assets (ROA), sedangkan variabel Quick Ratio tidak berpengaruh signifikan terhadap Return On Assets (ROA). Secara simultan variabel Current Ratio, Quick Ratio dan Cash Ratio berpengaruh signifikan terhadap Return On Assets (ROA).
\end{abstract}

Kata Kunci : Current Ratio, Quick Ratio, Cash Ratio, dan Return On Assets

\section{A. PENDAHULUAN}

Setiap perusahaan baik yang besar maupun kecil, yang berorientasi profit maupun non profit akan mempunyai perhatian yang besar terhadap keuangan dari perusahaan tersebut. Keberhasilan maupun kegagalan dalam usahanya hampir sebagian dipengaruhi ataupun ditentukan oleh keputusan keuangan perusahaan tersebut. Dengan kata lain masalah yang sering timbul dalam setiap organisasi berimplikasi terhadap bidang keuangan. Untuk menilai kinerja keuangan suatu perusahaan dapat kita ketahui melalui laporan keuangan perusahaan yang terdiri dari laporan neraca, laporan perhitungan laba rugi, laporan arus kas, laporan perubahan posisi keuangan. Laporan keuangan sangat penting untuk menilai prestasi dan kondisi ekonomis perusahaan. Dalam menilai kinerja keuangan perusahaan memerlukan beberapa tolak ukur. Tolak ukur yang sering digunakan adalah rasio atau indeks yang menghubungkan dua data keuangan yang satu dengan yang lainnya. Penilaian kinerja keuangan perusahaan merupakan salah satu cara yang dapat dilakukan oleh manajemen agar dapat memenuhi kewajibannya terhadap para penyandang dana dan juga untuk mencapai tujuan yang telah ditetapkan perusahaan. Likuiditas menunjukkan kemampuan suatu perusahaan untuk memenuhi kewajiban keuangannya yang harus segera dipenuhi atau saat ditagih, sedangkan profitabilitas mengukur kemampuan para eksekutif perusahaan dalam menciptakan tingkat keuntungan baik dalam bentuk laba perusahaan maupun nilai ekonomis atas penjualan, aset bersih perusahaan maupun modal sendiri. Rasio likuiditas dapat diukur dengan menggunakan beberapa rasio seperti 
current ratio (CR), quick ratio (QR) dan cash ratio sedangkan Rasio profitabilitas dapat diukur menggunakan beberapa rasio seperti profit margin, ROA dan ROE.

Likuiditas mempunyai hubungan yang cukup erat dengan kemampuan perusahaan memeroleh laba (profitabilitas), karena likuiditas menunjukkan tingkat ketersediaan modal kerja yang dibutuhkan dalam aktivitas operasional. Adanya modal kerja yang cukup memungkinkan bagi perusahaan untuk beroperasi secara maksimal dan tidak mengalami kesulitan akibat krisis keuangan. Akan tetapi, modal kerja yang berlebihan justru menunjukkan adanya dana yang tidak produktif dan terkesan perusahaan melepaskan untuk memeroleh keuntungan. Idealnya, modal kerja perusahaan seharusnya tersedia dalam jumlah yang cukup untuk membiayai berbagai kegiatan perusahaan, yang berarti tidak terdapat kekurangan modal dan tidak terdapat sumber daya yang menganggur.

Jika suatu perusahaan hanya memerhatikan likuiditasnya tetapi mengabaikan yang lainnya, akibatnya perusahaan mengambil kebijaksanaan dengan menyediakan uang kas dan alat-alat likuid lainnya dalam jumlah yang sangat besar. Hal ini dapat menimbulkan akibat bahwa sebagian besar modal lancar tidak produktif sehingga aktivitas perusahaan menjadi kurang lancar dan menyebabkan pula tingkat profitabilitas menurun atau bahkan mengalami kerugian. Sebaliknya apabila perusahaan hanya mengejar profitabilitas tanpa memerhatikan likuiditas perusahaan maka dapat menyebabkan kepercayaan pihak luar terhadap perusahaan berkurang. Berkurangnya kepercayaan pihak luar terhadap perusahaan akan mengakibatkan kerugian yang lebih besar lagi. PT. Matahari Putra Prima Tbk (MPPA) adalah perusahaan ritel di indonesia yang merupakan anak perusahaan dari grup lippo, didirikan pada tahun 1986, dan telah berhasil mengoperasikan sejumlah anak perusahaan yang terkait dalam berbagai bidang industri. Sejak penawaran perdana pada tahun 1992 , MPPA telah mempertahankan kinerja keuangan positif yang konsisten memberikan keuntungan solid bagi pemegang saham. Berikut tabel pertumbuhan tingkat likuiditas dan tingkat profitabilitas selama 10 tahun terakhir.

Tabel 1.

Pertumbuhan Tingkat Likuiditas dan Tingkat Profitabilitas pada PT. MATAHARI PUTRA PRIMA Tbk.

\begin{tabular}{|c|c|c|c|c|}
\hline \multirow{2}{*}{ Tahun } & \multicolumn{3}{|c|}{ Likuiditas } & $\begin{array}{c}\text { Kinerja } \\
\text { Keuangan }\end{array}$ \\
\cline { 2 - 5 } & $\begin{array}{c}\text { X1 } \\
\text { CR }(\%)\end{array}$ & $\begin{array}{c}\text { X2 } \\
\text { QR }(\%)\end{array}$ & $\begin{array}{c}\text { X3 } \\
\text { CSR }(\%)\end{array}$ & $\begin{array}{c}\text { Y(ROA) } \\
(\%)\end{array}$ \\
\hline 2008 & 112,1 & 90,4 & 38,4 & 1,0 \\
\hline 2009 & 161,1 & 123,8 & 71,6 & 2,84 \\
\hline 2010 & 176,5 & 145,0 & 83,7 & 2,9 \\
\hline 2011 & 122,0 & 79,2 & 47,4 & 1,2 \\
\hline 2012 & 187,2 & 125,7 & 50,1 & 12,9 \\
\hline 2013 & 137,2 & 62,3 & 43,0 & 6,7 \\
\hline 2014 & 141,9 & 45,4 & 27,1 & 9,4 \\
\hline
\end{tabular}




\begin{tabular}{|l|l|l|l|l|}
\hline 2015 & 141,0 & 43,1 & 14,5 & 12,9 \\
\hline 2016 & 123,0 & 40,6 & 17,3 & 15,0 \\
\hline 2017 & 164,1 & 23,3 & 19,6 & 11,9 \\
\hline
\end{tabular}

Sumber : data dari situs Bursa Efek Indonesia, (www.idx.co.id)

Berdasarkan tabel diatas menunjukkan bahwa current ratio pada PT.Matahari Putra Prima Tbk selama periode tahun 2008- 2017 kurang baik karena tren nya mengalami peurunan dan penaikan yang cukup signifikan. Dari penilaian rasio semakin tinggi nilai rasio maka akan semakin baik yaitu sebesar $200 \%$. Namun rasio ini tidak cukup mencapai $200 \%$ artinya perusahaan belum mampu menutupi kewajiban lancarnya. Persentase quick ratio dari tahun 2008-2017 mengalami penurunan yang cukup signifikan di tahun 2013-2017. Persentase cash ratio dari tahun 2008-2017 mengalami penurunan yang cukup signifikan ditahun 2014-2017. Sedangkan pada periode tahun 2008-2017, Adanya penurunan dari tahun ketahun Artinya perusahaan mengalami penurunan terhadap laba bersih yang diperoleh perusahaan yang diukur dari nilai aktiva.

Berdasarkan latar belakang tersebut, maka penulis tertarik untuk melakukan penelitian dengan judul "Pengaruh Rasio Likuiditas terhadap Kinerja Keuangan ditinjau dari Return On Assets (roa) pada PT.Matahari Putra Prima Tbk di Bursah Efek Indonesia.

\section{B. KAJIAN TEORI \\ D Rasio Likuiditas}

Houston

(2010:65)

mengemukakan likuiditas adalah kemampuan suatu perusahaan untuk memenuhi seluruh kewajiban yang segera harus dibayar. Sedangkan Kasmir (2011:32) juga mengemukakan Rasio Likuiditas merupakan rasio yang digunakan dalam mengukur seberapa likuid suatu perusahaan. Caranya adalah dengan membandingkan seluruh komponen yang ada di aktiva lancar dengan komponen di pasiva lancar (utang jangka pendek).

Tingkat likuiditas dapat diukur dengan menggunakan beberapa rasio, antara lain sebagai berikut:

1) Rasio lancar (Current Ratio)

Current ratio merupakan rasio lancar mengukur kemampuan perusahaan membayar kewajiban jangka pendek atau utang yang segera jatuh tempo pada saat ditagih. Dengan kata lain seberapa banyak aktiva lancar yang tersedia untuk menutupi kewajiban jangka pendek yang segera jatuh tempo. Rasio lancar dapat pula dikatakan sebagai bentuk untuk mengukur tingkat keamanan (margin of safety). Rumus untuk mencari current ratio yang dapat digunakan, sebagai berikut:

Current Ratio $=\frac{\text { Aktiva Lancar }}{H u \tan g \text { Lancar }} \times 100 \%$

2) Rasio cepat (Quick Ratio)

Quick ratio merupakan rasio uji cepat yang menunjukkan kemampuan perusahaan membayar kewajiban jangka pendek dengan aktiva lancar tanpa memperhitungkan persediaan. Hal ini disebabkan persediaan memerlukan waktu relatif lebih lama untuk diuangkan dibandingkan dengan aset lain, dengan kata lain, quick ratio diukur dari total aktiva lancar kemudian dikurangi dengan persediaan termasuk biaya yang diuangkan dibayar dimuka dan dibandingkan dengan seluruh utang lancar. Rumus yang dapat digunakan untuk mencari quick ratio sebagai berikut:

QuikRatio $=\frac{\text { AktivaLancar }- \text { Persediaan }}{H u \tan g \text { Lancar }} \times 100 \%$


3) Rasio kas (Cash ratio)

Cash ratio merupakan alat untuk mengukur seberapa besar uang kas yang tersedia untuk membayar utang. Hal ini dapat ditunjukkan dari tersedianya dana kas atau yang setara kas seperti rekening giro.

Rasio ini menunjukkan kemampuan sesungguhnya bagi perusahaan untuk membayar utangutang jangka pendeknya. Rumus untuk mencari cash ratio dapat digunakan sebagai berikut:

Cash Ratio $=\frac{\text { Kash (Bank) }}{H u \tan g \text { Lancar }} \times 100 \%$

\section{$>$ Rasio Profitabilitas}

Brigham

(2001:43)

mengemukakan bahwa rasio profitabilitas adalah rasio yang mengukur efektivitas manajemen yang ditunjukkan oleh laba yang dihasilkan dari penjualan dan investasi perusahaan. Napa J. Awat juga mengemukakan rasio profitabilitas berusaha mengukur kemampuan menghasilkan laba, baik dengan menggunakan seluruh aktiva yang ada maupun dengan menggunakan modal sendiri. Sedangkan Lukas Setia (2003:26) mengemukakan bahwa profitabilitas adalah kemampuan perusahaan untuk menghasilkan keuntungan dibandingkan dengan modal yang digunakan dan dinyatakan dalam persentase. Rasio ini terdiri dari:

1) Profit margin (profit margin on sales)

Rasio ini diukur antara profit margin dan penjualan, dan di ukur dalam persentase. Rumus untuk mencari profit margin sebagai berikut :

$$
\mathrm{NPM}=\frac{\text { Net } \mathrm{Pr} \text { ofit AfterTex }}{\text { Net } \text { Sales }}
$$

2) Return on Assets (ROA)

Return on Assets merupakan rasio yang menunjukkan hasil (return) atas jumlah aktiva yang digunakan dalam perusahaan atau suatu ukuran tentang efisiensi manajemen. Rasio ini menunjukkan mengabaikan sumber pendanaan dan biasanya rasio ini diukur dengan persentase. Rasio ini menunjukkan produktivitas dari seluruh dana perusahaan baik modal pinjaman maupun modal sendiri. Semakin kecil (rendah) rasio ini, semakin tidak baik, demikian pula sebaliknya. Artinya, rasio ini digunakan untuk mengukur efektivitas dari keseluruhan operasi perusahaan. Rumus untuk mencari return on Assets dapat digunakan sebagai berikut :

$\mathrm{ROA}=\frac{\text { Net } \text { Pr } \text { ofit AfterTax }}{\text { Total Assets }}$

3) Return on Equity (ROE)

Return on Equity atau rentabilitas modal sendiri merupakan rasio untuk mengukur laba bersih sesudah pajak dengan modal sendiri. Semakin tinggi rasio ini semakin baik. Artinya, posisi pemilik perusahaan semakin kuat, demikian pula sebaliknya. Rumus untuk mencari Return on Equity dapat digunakan sebagai berikut:

$$
\mathrm{ROA}=\frac{\text { Net } \operatorname{Pr} \text { ofit AfterTax }}{\text { Equity }}
$$

\section{Kerangka Berfikir}

Penelitian ini membahas mengenai Pengaruh rasio likuiditas terhadap kinerja keuangan di tinjau dari return on assets (roa) pada PT.Matahari Putra Prima Tbk di Bursah Efek Indonesia. Berdasarkan latar belakang dan tinjauan pustaka diatas, maka dapat digambarkan sebuah kerangka pemikiran teoritis seperti pada gambar berikut : 


\section{Kerangka Berfikir}

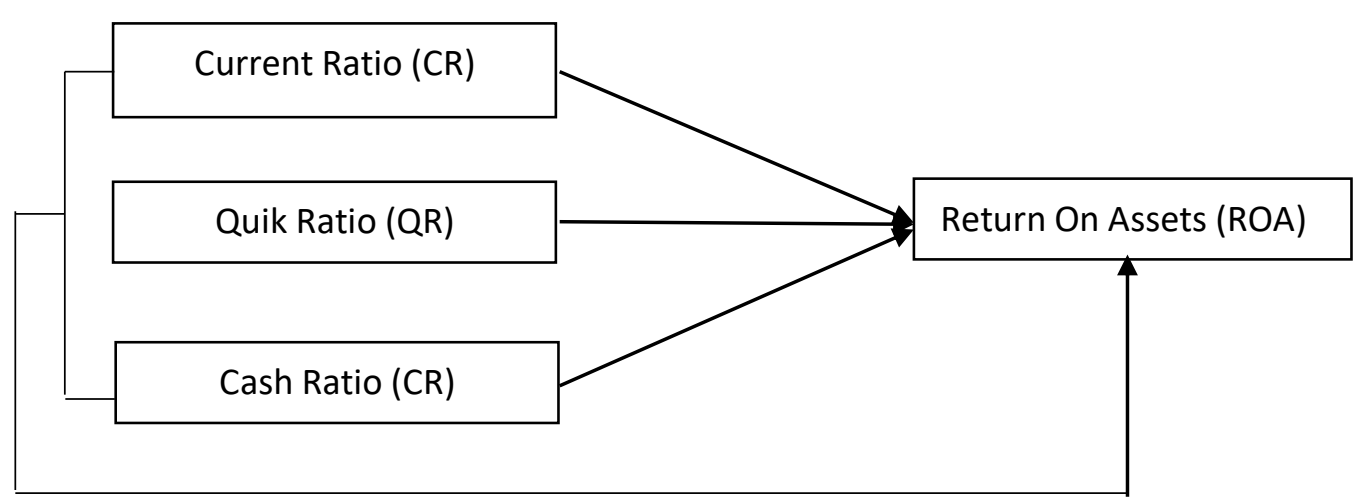

Dari Gambar diatas dapat dijelaskan bahwa Apakah ada pengaruh secara parsial Current Ratio, Quick Ratio,dan Cash Ratio terhadap Return On Asests (ROA). Dan apakah ada pengaruh secara simultan Current Ratio, Quick Ratio,dan Cash Ratio terhadap Return On Asests (ROA).

\section{- Hipotesis}

1. Diduga ada pengaruh signifikan antara Rasio likuiditas (CR,QR,CR) terhadap kinerja keuangan ditinjau dari ROA pada PT.MATAHARI PUTRA PRIMA

2. Diduga ada pengaruh signifikan antara Rasio likuiditas (CR) terhadap kinerja keuangan ditinjau dari ROA pada PT.MATAHARI PUTRA PRIMA TBK.

3. Diduga ada pengaruh signifikan antara Rasio likuiditas (QR) terhadap kinerja keuangan ditinjau dari ROA pada PT.MATAHARI PUTRA PRIMA TBK.

4. Diduga ada pengaruh signifikan antara Rasio likuiditas (CR) terhadap kinerja keuangan ditinjau dari ROA pada PT.MATAHARI PUTRA PRIMA TBK

\section{METODE PENELITIAN}

Pada penelitian ini penulis menggunakan penelitian Asosiatif / Kuantitatif untuk mengtahui variabel bebas terhadap variabel terkait. Jadi dalam penelitian ini untuk mengetahui
Pengaruh Rasio Likuiditas terhadap Kinerja Keuangan ditinjau dari Return On Assets (ROA) pada PT.Matahari Putra Prima Tbk. Populasi dalam penelitian ini adalah Laporan Keuangan PT Matahari Putra Prima Tbk yang tercatat di Bursa Efek Indonesia. Data yang digunakan adalah data time series yaitu laporan keuangan PT.Matahari Putra Prima Tbk selama 10 tahun, data yang digunakan dari tahun 2008 sampai dengan tahun 2017. Sumber data yang digunakan dalam penelitian ini adalah data sekunder yang bersifat kuantitatif. Data sekunder umumnya berupa bukti, catatan, laporan historis yang telah tersusun dalam laporan keuangan tahunan yang diperoleh di situs internet yaitu https://idx.co.id. pada periode pengamatan tahun 2012-2016. dan sumber-sumber lain yang penulis peroleh dari beberapa buku, jurnal, makalah dan hasil penelitian yang berhubungan dengan penelitian ini. Penelitian ini menggunakan uji statistik Regresi Linier Berganda dengan terlebih dahulu menentukan uji asumsi klasik. Pengujian hipotesis dengan menggunakan Uji t, Uji $F$, Analisis Korelasi Ganda dan Uji Koefisien Determinasi.

E. PEMBAHASAN

- Pengaruh antara Rasio likuiditas (CR,QR,CR) secara simultan terhadap kinerja keuangan 


\section{ditinjau dari ROA pada PT.MATAHARI PUTRA PRIMA}

Uji $F$ digunakan untuk menjelaskan variabel bebas (X1) secara serentak atau simultan terhadap variabel terikat $(\mathrm{Y})$. Uji $\mathrm{F}$ ditujukan untuk mengukur tingkat keberartian hubungan secara keseluruhan koefisien regresi dari variabel bebas terhadap variabel terikat. Adapun hasil perhitungannya adalah :

Tabel 2

Hasil Uji F (Simultan)

ANOVA $^{a}$

\begin{tabular}{|c|c|c|c|c|c|c|}
\hline \multicolumn{2}{|c|}{ Model } & $\begin{array}{c}\text { Sum of } \\
\text { Squares }\end{array}$ & Df & $\begin{array}{l}\text { Mean } \\
\text { Square }\end{array}$ & $\mathrm{F}$ & Sig. \\
\hline \multirow[t]{3}{*}{1} & Regression & 215,983 & 3 & 71,994 & 9,248 &, $011^{b}$ \\
\hline & Residual & 46,710 & 6 & 7,785 & & \\
\hline & Total & 262,693 & 9 & & & \\
\hline
\end{tabular}

a. Dependent Variable: $y$

b. Predictors: (Constant), $x 3, x 1, x 2$

Sumber : Hasil pengolahan data dengan SPSS 17.0

Berdasarkan tabel diatas, mununjukkan bahwa nilai $F_{\text {hitung }}$ lebih besardari dari $F_{\text {tabel }}(9,248>4,35)$. Hasil ini menunjukkan bahwa variabelvariabel Current Ratio, Quick Ratio dan Cash Ratio secara

simultan atau serentak merupakan penjelas yang signifikan terhadap return on assets. Hubungan linier dariketiga variabel secara serentakberpengaruh signifikan, yang ditunjukkan nilai signifikansi $F$ yang mencapai angka 0.011 .
- Pengaruh antara Rasio likuiditas (CR,QR,CR) secara parsial terhadap kinerja keuangan ditinjau dari ROA pada PT.MATAHARI PUTRA PRIMA

Uji-t digunakan untuk menguji dan mengetahui pengaruh variabel Current Ratio, Quick Ratio,dan Cash Ratio secara parsial terhadap tingkat profitabilitas (ROA). Hasil pengujian hipotesis dengan uji t pada signifikansi $a=5 \%$ adalah sebagai berikut :

Tabel 3

Hasil Uji t (Parsial)

Coefficients $^{\mathrm{a}}$

\begin{tabular}{|ll|r|r|r|r|r|}
\hline \multirow{2}{*}{ Model } & \multicolumn{2}{|c|}{$\begin{array}{c}\text { Unstandardized } \\
\text { Coefficients }\end{array}$} & $\begin{array}{c}\text { Standardized } \\
\text { Coefficients }\end{array}$ & & \\
\cline { 2 - 4 } & \multicolumn{1}{|c|}{ B } & Std. Error & \multicolumn{1}{c|}{ Beta } & \multicolumn{1}{c|}{ T } & \multicolumn{1}{c|}{ Sig. } \\
\hline 1 & (Constant) & $-4,102$ & 5,664 & &,- 724 &, 496 \\
& x1 &, 143 &, 043 &, 656 & 3,325 &, 016 \\
x2 &, 035 &, 058 &, 275 &, 608 &, 566 \\
x3 &,- 288 &, 104 & $-1,232$ & $-2,757$ &, 033 \\
\hline
\end{tabular}

a. Dependent Variable: $y$

Sumber : Hasil pengolahan data dengan SPSS 17.0 
- Pengaruh Current Rattio (X1) terhadap ROA

Berdasarkan hasil analisis regresi diperoleh nilai thitung $>t_{\text {tabel }}(3,325>$ $2,447)$ dan nilai signifikansi $0.016<$ 0.05. Maka dapat disimpulkan bahwa $\mathrm{H} 0$ ditolak dan $\mathrm{H} 1$ diterima, yang artinya Current Ratio (X1) berpengaruh signifikan terhadap ROA $(\mathrm{Y})$.

\section{- Pengaruh Quick Ratio (X2) terhadap ROA}

Berdasarkan hasil analisis regresi diperoleh nilai $t_{\text {hitung }}<t_{\text {tabel }}(0,608<$ $2,447)$ dan nilai signifikansi $0.566>$ 0.05 . Maka dapat disimpulkan bahwa $\mathrm{H} 0$ diterima dan $\mathrm{H} 1$ ditolak, yang artinya Quick Ratio (X1) tidak berpengaruh signifikan terhadap ROA $(\mathrm{Y})$.

\section{- Pengaruh Cash Ratio (X3) terhadap ROA}

Berdasarkan hasil analisis regresi diperoleh nilai thitung $>$ tabel $(-2,757>$ $2,477)$ dan nilai signifikansi $0.033<$ 0.05 . Maka dapat disimpulkan bahwa $\mathrm{H} 0$ ditolak dan $\mathrm{H} 1$ diterima, yang artinya Quick Ratio (X1) berpengaruh negatif signifikan terhadap ROA (Y).

\section{F. KESIMPULAN}

Berdasarkan hasil analisis data dan pembahasan yang telah dilakukan, maka penulis mengambil bebrapa kesimpulan sebagai berikut:

1. Secara simultan variabel Current Ratio, Quick Ratio dan Cash Ratio berpengaruh signifikan terhadap Return On Assets (ROA), yang ditunjukan dengan nilai $F_{\text {hitung lebih }}$ besar dari dari $F_{\text {tabel }}$ $(9,248>4,35) \cdot d a n$ tingkat signifikansinya 0.011 .

2. Secara parsial variabel Current Ratio berpengaruh signifikan terhadap Return On Assets (ROA), nilai thitung lebih besar dari tabel
(3,325> 2,447) dan nilai signifikansi 0.016 lebih kecil dari 0.05 ..

3. Secara parsial variabel Quick Ratio tidak berpengaruh signifikan terhadap Return On Assets (ROA), yang ditunjukannilai thitung lebih kecil dari tabel $(0,608<2,447)$ dan nilai signifikansi 0.566 lebih besar dari 0.05

4. Secara parsial variabel Cash Ratio berpengaruh negatif signifikan terhadap Return On Assets (ROA), yang ditunjukannilai thitung lebih besar dari tabel $(-2,757>2,477)$ dan nilai signifikansi 0.033 lebih kecil dari 0.05

\section{DAFTAR PUSTAKA}

Atmajaya, Lukas Setia (2003). Manajemen Keuangan. Edisi Revisi. Yogyakarta: Andi.

Brigham, Houston (2010). Dasar dasar manajemen keuangan Buku 1 Edisi 11,Salemba Empat.

Eugene F. Brigham, Joel F. Houston. 2001. Manajemen Keuangan. Jakarta:Erlangga.

Guspiati, Shopi (2011). Analisis Pengaruh Rasio Likuiditas Terhadap Rasio Profitabilitas Pada PT. Hilon Sumatera Medan, Skripsi. Medan: Universitas Sumatera Utara.

Hanafi,Ma mduh. Analisis Laporan Keuangan (2003) Jakarta: Unit Penerbit dan Percetakan Akademi Manajemen Perusahaan Yayasan Keluarga Pahlawan Negara. 
Harmono (2011). Manajemen keuangan: berbasis balanced scorecard,Jakarta bumi aksara.

Irawan, Nizwar. (2012). Pengaruh Rasio Likuiditas Terhadap Rasio profitabilitas pada Bank Syari"ah di Indonesia (Studi Kasus Tahun 2007-2009). Skripsi. Semarang: Institut Agama Islam Negeri Walisongo.
Kasmir. 2011. Analisis Laporan Keuangan. Jakarta: Raja Grafindo Persada.

Raharjaputra, Hendra S (2009). Buku Panduan Praktis Manajemen Keuangan dan Akuntansi untuk Eksekutif Perusahaan. Jakarta: Salemba Empat.

Sugiyono 2012. Metodologi Penelitian Kuantitatif Kualitati. Bandung Alfhabeta 